
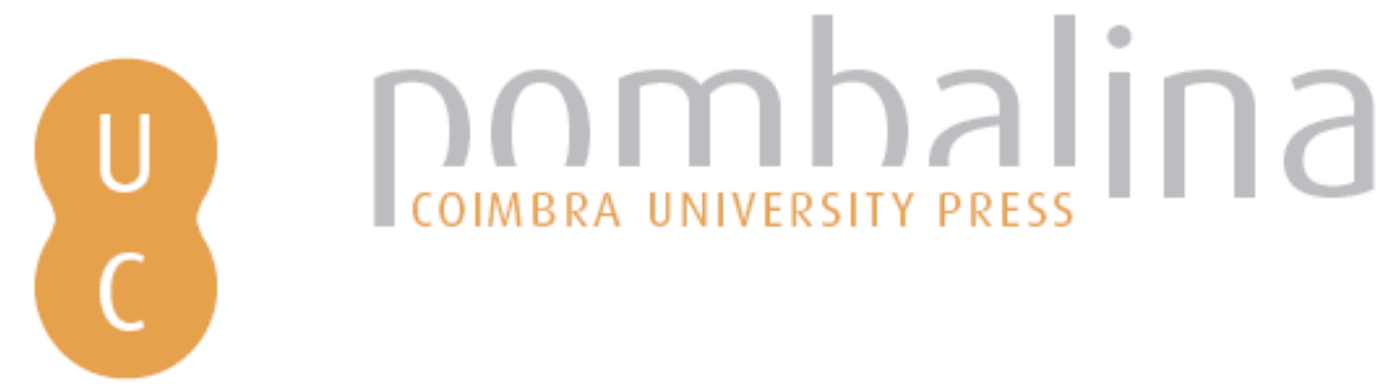

\title{
The role of feedback from teachers in the perspective of future development of young's career attending courses EFA and PIEF
}

\author{
Autor(es): $\quad$ Martins, Dulce; Carvalho, Carolina \\ Publicado por: Imprensa da Universidade de Coimbra \\ URL \\ persistente: URI:http://hdl.handle.net/10316.2/38625 \\ DOI: $\quad$ DOI:http://dx.doi.org/10.14195/978-989-26-0775-7_21 \\ Accessed : $\quad$ 26-Apr-2023 11:01:32
}

A navegação consulta e descarregamento dos títulos inseridos nas Bibliotecas Digitais UC Digitalis, UC Pombalina e UC Impactum, pressupõem a aceitação plena e sem reservas dos Termos e Condições de Uso destas Bibliotecas Digitais, disponíveis em https://digitalis.uc.pt/pt-pt/termos.

Conforme exposto nos referidos Termos e Condições de Uso, o descarregamento de títulos de acesso restrito requer uma licença válida de autorização devendo o utilizador aceder ao(s) documento(s) a partir de um endereço de IP da instituição detentora da supramencionada licença.

Ao utilizador é apenas permitido o descarregamento para uso pessoal, pelo que o emprego do(s) título(s) descarregado(s) para outro fim, designadamente comercial, carece de autorização do respetivo autor ou editor da obra.

Na medida em que todas as obras da UC Digitalis se encontram protegidas pelo Código do Direito de Autor e Direitos Conexos e demais legislação aplicável, toda a cópia, parcial ou total, deste documento, nos casos em que é legalmente admitida, deverá conter ou fazer-se acompanhar por este aviso.

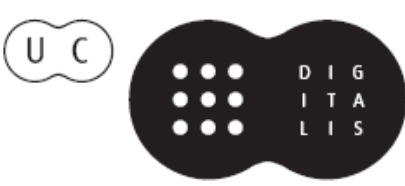




\section{INTERNATIONAL \\ STUDIES IN TIME \\ PERSPECTIVE}

MARIA PAULA PAIXÃO

JOSÉ TOMÁS DA SILVA

(COORD.)

VICTOR ORTUÑO

PEDRO CORDEIRO

(EDITORS)

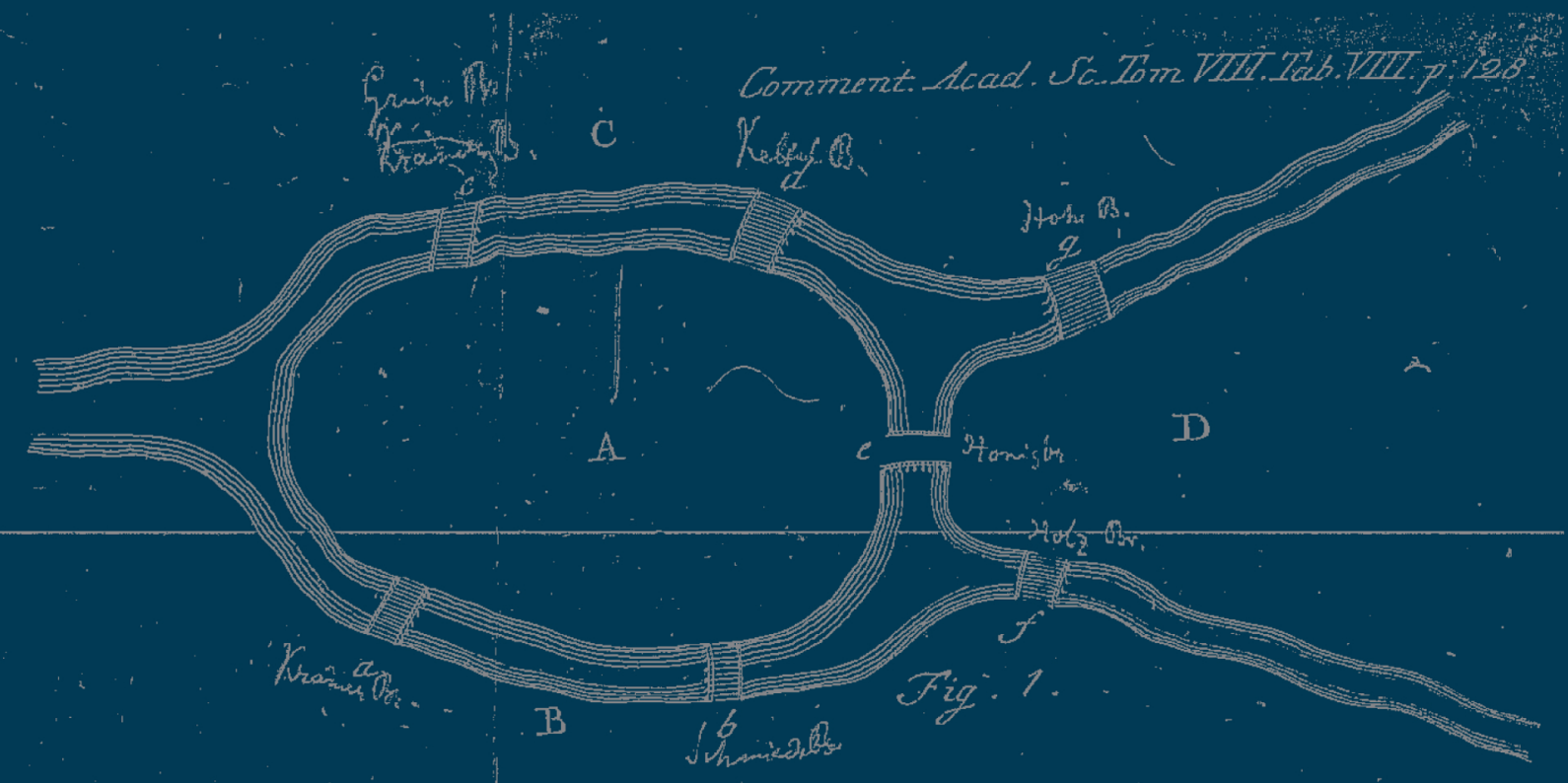

IMPRENSA DA

UNIVERSIDADE

DE COIMBRA

COIMBRA

UNIVERSITY

PRESS 
Chapter 21

THE ROLE OF FEEDBACK FROM TEACHERS IN THE PERSPECTIVE OF FUTURE DEVELOPMENT OF YOUNG'S CAREER ATTENDING COURSES EFA AND PIEF

\author{
Dulce Martins \\ Carolina Carvalho \\ Institute of Education of the University of Lisbon, Portugal \\ dulcemartins24@portugalmail.pt \\ cfcarvalho@ie.ul.pt
}

\begin{abstract}
Aвsтract: This paper intends to clarify how the teachers' feedback influences the development of perspective for the future of young people attending professional courses of Education and Training of Adults (EFA), and an integrated programme of education and training (PIEF), in the Lisbon metropolitan area. The main goal is to understand how young people at this stage of their lives, while professional school students, perspective the choice or the decision of a professional future, through the feedback from teachers about their school results and their educational trajectories. In this study, 42 youths participated in Lisbon, of which 31 were attending professional courses EFA and 11 integrate a PIEF group. These young participants were between 13 and 19 years. The methodological plan used included, in addition to collecting socio-demographic identification data, the application of a questionnaire with six issues of open response and the scale Dellas Identity Status Inventory-Occupation (DISI-O; Dellas \& Jernigan, 1981, adapted by Taveira, 1986), to evaluate the development modes of construction of identity of a future career through feedback from teachers. The generality of the results at scale DISI-O dimensions, it was possible to verify that the young people show contrasting results in the statuses Foreclosure and Moratorium. These results seem to indicate that although these young people are attending a professional course, show little engagement in exploring development options and career building, and therefore have difficulty in making safe decisions or choices, especially the younger ones.
\end{abstract}

Keywords: feedback, teachers, youth, career, EFA and PIEF courses.

\title{
INTRODUCTION
}

Education policies followed in Portugal, based on benchmarks of European Union (e.g. European Council, 2006, 2007; UNESCO, 2000) highlighted the importance of the role of formal education of young people, which occurs in school context, in the construction and development of essential skills to preparing young people for active life (Carvalho et al, 2008). Being one of the missions of the school encourage the appropriation of knowledge, enabling young people to become active citizens, the role of feedback from teachers is an effective resource in the creation of opportunities for exploration, interaction and relationship in the development of young's future career perspectives (Almeida, 2008; Coimbra, 1995; Taveira, 2000; Veiga \& Moura, 2005, Vega, 2009). 
Some recent research on meta-analysis explain feedback is "the most powerful influences on achievement" (Hattie, 2009, p.173). In model of feedback proposed by Hattie and Timperley (2007), it is recognized the importance of feedback in the formative process of questions like "where am i going", "How am i going" and "where to next". The feedback effect integrates the temporal flow of personal and formative experiences, as the parties of past, present and future (Zimbardo \& Boyd, 1999). In this sense, it seems for us, that the feedback acquires a fundamental role in the development and vocational guidance of young people, to help in choices and decisions for a future job or profession (Savickas, 1997/1998).

\section{Methodology}

\section{Participants and procedure}

In this study participated 42 young people (all male), between 13 and 19 years old $(\mathrm{M}=16.5$ and $\mathrm{DP}=1.46)$. These young people integrated 4 courses, one of them being equivalent of 5 and 6 grade and the remaining three that had professional curricula (courses of Education and Training of Adults-EFA) at the 7,8 and 9 grades of elementary school. The respective courses was designated: Integrated Programme of Education and Training (PIEF), Waiter, Kitchen and Maintenance Hotel Operator (OMH). Filling in the questionnaires was supervised by the investigator in the courses above mentioned. This task took place in the normal hours of the courses training and the youths collaborated voluntarily, taking up all the time that was necessary to fill in the questionnaires properly.

\section{Instruments}

It was used Dellas Identity Status Inventory Occupation scale (DISI-O) that has already been adapted to the Portuguese population by Taveira (1986), has 35 items sorted into 5 statutes of vocational identity, similar to the taxonomy developed by Marcia $(1964,1966)$ : achievement, moratorium, foreclosure, and diffusion-diffusion and diffusion-luck. We also used a open-end questionnaire with six issues to assess how these young people perceived the feedback from teachers in the construction and development of vocational identity.

\section{RESULTS}

On the analysis and discussion of the results of this study, had taken into account the following central goals: a) Evaluate the characteristics of vocational identity of young participants, according to age and the courses; b) knowing the perceptions of young participants about the feedback from teachers in the development of perspectives of professional future. 


\section{Characteristics of vocational identity of young participants}

In Table 1, is organized the data collected through the DISI-O scale to evaluate the characteristics of the vocational identity of young participants, according to age and courses in training. In this Table, the age of young participants was considered in three groups. These age groups are designed based on the mean of age of young participants.

Table1 - Statistical elements according to age and courses in training of young participants

\begin{tabular}{|c|c|c|c|c|c|c|c|c|c|c|c|}
\hline \multirow{3}{*}{ Course } & \multirow{3}{*}{$\begin{array}{l}\text { Mean } \\
\text { (in } \\
\text { years) }\end{array}$} & \multicolumn{10}{|c|}{ Statutes of Vocational Identity } \\
\hline & & \multicolumn{2}{|c|}{ Achievement } & \multicolumn{2}{|c|}{ Moratorium } & \multicolumn{2}{|c|}{ Foreclusure } & \multicolumn{2}{|c|}{ Diffusion-Diffusion } & \multicolumn{2}{|c|}{ Diffusion-Luck } \\
\hline & & M & $\begin{array}{c}\text { Std. } \\
\text { Deviation }\end{array}$ & M & $\begin{array}{c}\text { Std. } \\
\text { Deviation }\end{array}$ & M & $\begin{array}{c}\text { Std. } \\
\text { Deviation }\end{array}$ & M & $\begin{array}{c}\text { Std. } \\
\text { Deviation }\end{array}$ & M & $\begin{array}{c}\text { Std. } \\
\text { Deviation }\end{array}$ \\
\hline $\operatorname{PIEF}(\mathrm{N}=14)$ & 15,5 & 21,3571 & 6,80053 & 24,8571 & 5,9337 & 19,2142 & 7,62766 & 23,5000 & 5,14033 & 21,9286 & 5,83707 \\
\hline $\begin{array}{l}\text { Waiter } \\
(\mathrm{N}=9)\end{array}$ & 16,7 & 25,7777 & 5,51764 & 27,7777 & 6,74124 & 22,6666 & 6,87386 & 23,6666 & 7,07106 & 22,2222 & 5,09356 \\
\hline Kitchen $(\mathrm{N}=9)$ & 16,4 & 24,6666 & 3,24037 & 25,8888 & 4,45658 & 21,6666 & 4,27200 & 24,3333 & 2,91547 & 22,6666 & 3,53553 \\
\hline $\mathrm{O} M \mathrm{H}(\mathrm{N}=10)$ & 17,8 & 25,0000 & 6,27162 & 25,9000 & 5,40473 & 19,7000 & 4,49814 & 22,0000 & 5,51764 & 21,0000 & 6,78233 \\
\hline
\end{tabular}

In general, the results obtained through the application of the scale DISI-O, allow us to find a line with the vocational identity theory and with previous studies (e.g. Dellas \& Jernigan, 1981; Taveira, 1986, 2000; Taveira \& Campos, 1987; Blustein \& Noumair, 1996; Veiga \& Moura, 2005). In particular, in terms of vocational identity, most of the young participants, are in full period of adolescence, stays in the status of identity moratorium, which is characterised by young people who are living a period of exploration of the issues of identity, expressing difficulty in making choices. In this situation, we also realize that in spite of the young participants in this study are attending professional courses, which main goal is essentially enable them acquiring essential skills for a future career, these ones reveal difficulties in defining a vocational guidance.

Perceptions of young people about the feedback from teachers in the development of the future career

From the 42 young participants, only 38 completed the open-end questionnaire. In this study, from the 6 issues worked in questionnaire, we present the following questions:

- In the assessments that you receive from teachers, did you ever feel that this was the course that you wanted to attend to find a job/profession?"

- Do you think important that teachers advise or explain which course/profession/job you should choose?

The construction of categories consisted of group, by content similarity, the justifications given by young people for each of the questions in open-end format (Bardin, 1977; Patton, 1990). The categories and the frequency are present in Tables 2 and 3. 
- Open-end responses. Emergent response categories are presented in Table 2 regarding the question, "In the assessments that you receive from teachers, did you ever feel that this was the course that you wanted to attend to find a job/profession?"

Table 2 - Emergent Categories: "In the assessments that you receive from teachers, did you ever feel that this was the course that you wanted to attend to find a job/profession?"

\begin{tabular}{|l|l|c|}
\hline Category & Answer & Frequency \\
\hline \multirow{3}{*}{ Interest } & "Yes, when I joined this training, I felt that this was the right course" & 8 \\
\cline { 2 - 3 } & "Yes, because the teachers tell me that I have got the way" & 4 \\
\cline { 2 - 3 } & $\begin{array}{l}\text { "Yes, when teacher praises me and says that I have way, gives me more desire to } \\
\text { follow the course" }\end{array}$ & 5 \\
\hline \multirow{2}{*}{ Disinterest } & "No" & 13 \\
\cline { 2 - 3 } & "No, because the course has nothing to do with me" & 5 \\
\hline \multirow{2}{*}{ Indecision } & "I don't know", "Not at all, it is too early" & 3 \\
\cline { 2 - 3 } & Not answered & 38 \\
\hline & Total & 1 \\
\hline
\end{tabular}

Table 3 - Emergent Categories: "Do you think important that teachers advise or explain which course/profession/job you should choose?"

\begin{tabular}{|l|l|c|}
\hline Category & Answer & Frequency \\
\hline \multirow{4}{*}{$\begin{array}{l}\text { Guidance of vocacional } \\
\text { Comments }\end{array}$} & $\begin{array}{l}\text { "Yes, because teachers have more ability to say what we should fol- } \\
\text { low and what is best for us" }\end{array}$ & 10 \\
\cline { 2 - 3 } Career Comments & $\begin{array}{l}\text { "Yes, because teachers are daily with me and know what I have } \\
\text { way/capacity" }\end{array}$ & 2 \\
\hline \multirow{3}{*}{ Disinterest } & $\begin{array}{l}\text { "Yes, because they have years of life and experience" } \\
\text { "Yes, because young people as me do not care much to this issue } \\
\text { [job], they give time to time, which appear is well" }\end{array}$ & 2 \\
\cline { 2 - 3 } & "yes" & 6 \\
\hline & "No, because I think I have to make that decision" & 9 \\
\cline { 2 - 3 } & $\begin{array}{l}\text { "No, because the profession I choose will depend on the way and } \\
\text { the commitment and love that I will have for " }\end{array}$ & 2 \\
\cline { 2 - 3 } & "No" & 2 \\
\hline Indecision & "I do not agree or disagree" & 38 \\
\hline Total & & 2 \\
\hline
\end{tabular}

The most frequently cited response implicated disinterest. The young participants considered the feedback is not relevant, maybe because some of them are not identify themselves with the course "... the course has nothing to do with me" or simply by feel 
undecided and consider is "... too early" to reflect on this issue. However, 17 of the 38 responses think that de comments from teachers are motivators. As in the study of Hattie (2003) "It is what teachers know, do, and care about which is very powerful" (p.2) in the achievement process, because teachers are the ones who most be able to monitor, understand, and interpret students with more insight. "As a consequence they seek and provide more and better feedback in light of this monitoring" (p.8).

Emergent response categories in Table 3 are concerned about the question "Do you think important that teachers advise or explain which course/profession/job you should choose?"

In Table 3 is possible to see that the majority of the answers of the young participants consider teachers' opinion important for to have a choice in a future career. They consider that teachers provide effective feedback "...because they have years of life and experience", helping them to better identify the individual skills "...because teachers are daily..." present with their students. 2 of the 38 young's also consider that the feedback from teachers are important because young people "...do not care much to this issue, they give time to time, which appear is well" and in this way teachers can encourage students student to think in future. In this way, like in above the discussion of Table 2, teachers are seen by the young's as experts who monitoring some problems providing relevant and useful feedback (Hattie, 2003).

\section{Final Considerations}

In a society, where teachers have a strong influence on personal and social development of young people, the feedback is an important component of pedagogical process, which provide support of the development of the perception of future career of young people (Brookhart, 2008).

According to the results of this work, it is possible to understand the importance that the young participants give to feedback as a guidance practice to develop their vocational identity, because the majority of young people are in a phase of identity moratorium, in which not yet reveal the ability to make choices or elaborate coherent projects for a future career. It is perhaps in this way that in second analysis of youth answers from the open-end questionnaire, it is possible to understand that the majority of young people considers the feedback from teachers, is a consequent practice, since teachers are seen as experienced professionals of school pathways of their students. As such, the feedback comments are mostly understood as motivators, coaches and clarifiers of future perspective of career development and construction.

One of the feedback advantage is that it is aligned with many of best practices associated planning and development vocational choices and life projects of young people (Almeida, 2008; Brookhart, 2008; Taveira, 2000; Veiga \& Moura, 2005, Fisher \& Frey, 2007; Vega, 2009). In the Hattie (2003) opinion the feedback is "the most powerful single moderator that enhances achievement" (p. 8)

The feedback has generally positive effects in classroom interventions as an educational guidance for promoting the development of future career perspectives (Hattie, 2009). This guidance practice in school context has numerous advantages in personal and social training of our young people, since for many of them school can be a single opportunity 
to support the process of construction and development of vocational identity, allowing them access to vocational training and thus facilitating the transition to active life (Taveira, 2000, 2004). In Savikas (2005) opinion, "the goal of the school-to-work transition is that emerging adults learn to contribute to society by fitting their personalities into suitable work roles. The social expectation that adolescents seek occupations congruent with their abilities and interests is communicated to them in the form of vocational development tasks" (p.49). This transition between school and a future career, in addition to helping youth in their vocational choices, promoting the social inclusion of young people, helping them in their integration into the workforce.

\section{REFERENCES}

Almeida, M. E. G. G. (2008). (Re)pensando a Orientação Vocacional na Escola: Da teoria à Prática. Dissertação tese de mestrado. Aveiro: Universidade de Aveiro.

Bardin, L. (1977). Análise de Conteúdo. Lisboa: Ediçōes 70.

Blustein, D. L., \& Noumair, D. A. (1996). Self and Identity in Career Development: Implications for Theory and Practice. Journal of Counseling \& Development. 74, 433-441.

Broокнart, S. M. (2008). How to Give Effective Feedback to your Students. Virginia USA: Association for Supervision and Curriculum Development.

Carvalho, C., Freire, S., Baptista, M., Freire, A., Azevedo, M., \& Oliveira, T. (2008). Changing practices, changing identities: a study with students at risk of educational exclusion. In: A. Ross (Ed), Reflecting on Identities. London: CiCe.

Coimbra, J. L. (1995). Os Professores e a Orientação Vocacional. Noesis, 26-29. Porto: FPCE Universidade do Porto.

Dellas. M., \& Jerningan, L.P. (1981). Development of an objective instrument to measure identity status terms of occupation crisis and commitment. Educational and Psychological Measurement, 41, 1039-1050.

European Council (2006). Progress towards the Lisbon objectives in education and training. Brussels: European Council.

European Council (2007). Schools for the 21st century. Brussels: European Council.

FISHER, D., \& FREY, N. (2007). Checking for understanding: formative assessment techniques for your classroom. Virginia USA: Association for Supervision and Curriculum Development.

Hattie, J. (2003). Teachers Make a Difference. What is the research evidence? Australian Council for Educational Research. Australia:University of Auckland.

Hattie, J., \& Timperley, H. (2007). Review of Educational Research. 77 (1), 81-112.

Hatтie, J. (2009). Visible Learning:a synthesis of over 800 meta-analises relating to achievement. London and New York: Routledge.

Marcia, J. E. (1964). Determination and construct validity of ego identity status. Unpublished doctoral dissertation. Ohio: Ohio State University.

Marcia, J. E. (1966). Development and validation of ego-identity status. Journal of Personality and Social Psychology, 3, 551-559.

Patton, M. (1990). How to use qualitative methods in evaluation. Newbury Park: Sage.

SAvickas, M. L. (1997/1998) New developments in career theory and practice. Cadernos de Consulta Psicológica, 13-19. 
Savickas, M. L. (2005). “The Theory and Practice of Career Construction.” In S. D. Brown and R. W. Lent (Ed), Career Development and Counseling: Putting Theory and Research to Work. Hoboken, NJ: John Wiley \& Sons.

UNESCO (2000). Education for All Forum. Paris: UNESCO.

Taveira, M. C. (1986). Identidade e desenvolvimento vocacional nos jovens. Dissertação Tese de Mestrado. Porto: Universidade do Porto.

Taveira, M. C. (2000). Exploração e Desenvolvimento Vocacional de Jovens: Estudo sobre as Relações entre a Exploração, a Identidade e a Indecisão Vocacional. (Tese de doutoramento publicada) Braga: Centro de Estudos em Educação e Psicologia, Instituto da Educação e Psicologia da Universidade do Minho.

TAveira, M. C. (2004). Os serviços de desenvolvimento vocacional em Portugal: algumas notasestímulo para reflexão. Psychologica, Extra-série (número de homenagem ao Prof. Doutor Manuel Viegas de Abreu), 213-234.

TAveira, M. C., \& Campos, B. P. (1987). Identidade Vocacional de Jovens: Adaptação de uma Escala (DISI-O). Cadernos de Consulta Psicológica, 3, 55-67.

Vega, L. S. (2009). Orientación educativa e intervención psicopedagógica - Cambian los tiempos, cambian las responsabilidades profisionales. Madrid: Ediciones Prirámide.

Veiga, F. H., \& Moura. H. (2005). Adolescents' vocational identity: Adaptation of the occupational identity scale (OIS). Actas da International conference AIOSP 2005: Careers in context: new challenges and tasks for guidance and counseling. Lisbon: University of Lisbon, FPCE, AIOSP.

Zimbardo, P. G., \&, Boyd, J. N. (1999). Putting time in perspective: A valid, reliable individualdifferences metric. Journal of Personality and Social Psychology, 77, 1271-1288. 